\title{
FORMULATION AND EVALUATION OF SUSTAINED RELEASE TABLETS CONTAINING ANTIOXIDANTS
}

\author{
J. Cantoni ${ }^{1}$, S. Shawky Tous ${ }^{2 *}$, B. Bataille ${ }^{1}$, P. Prinderre ${ }^{3}$, J. P. Reynier ${ }^{3}$ and \\ S. Hansel-Esteller ${ }^{1}$ \\ ${ }^{1}$ Department of Pharmacy, Lapeyronie Hospital, Montpellier, France \\ ${ }^{2}$ Department of Pharmaceutics, Faculty of Pharmacy, Assiut University, Assiut, Egypt \\ ${ }^{3}$ Department of Galenic Pharmacy and Biopharmacy, Faculty of Pharmacy, Marseille, France
}

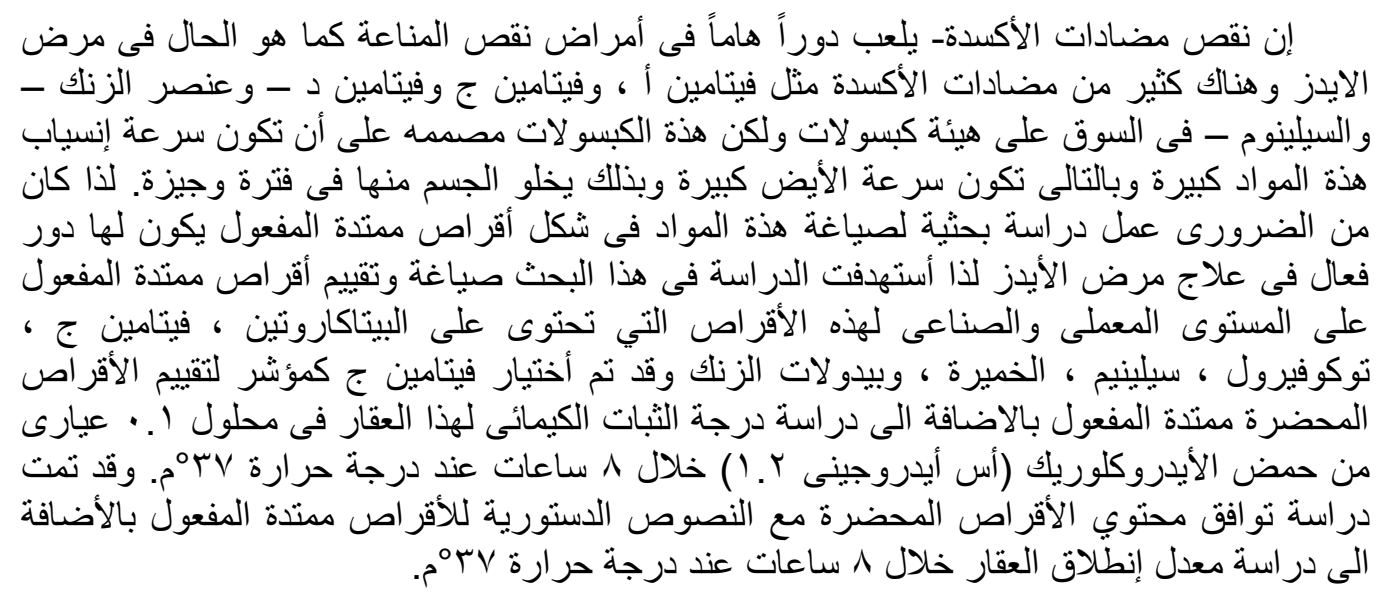

Deficiency in nutrients especially antioxidants play an important role in the pathogenesis of acquired immuno-deficiency syndrome (AIDS). Antioxidants; vitamin A, vitamin $C$, vitamin $E$, zinc and selenium are available in market as capsules. The release rate is very fast followed by fast elimination. It is necessary to prolong the residence time of antioxidants. Sustained release tablet formulation was designed and evaluated on small scale and on large scale preparations. Low attention has been discuss the use of sustained release formula in treatment of AIDS. Sustained release tablet formulation was designed and evaluated on small scale and on large scale preparations. The formulated tablets contained beta-carotene, vitamin $C$, tocopherol acetate, selenium, yeast and zinc pidolate. Vitamin $C$ was chosen as tracer for detection and evaluation of tablet dosage form. Vitamin $C$ was found to be stable in $0.1 \mathrm{~N} \mathrm{HCl}$ ( $\mathrm{pH}$ 1.2) along $8 \mathrm{hrs}$ at $37^{\circ} \mathrm{C}$. The formulated tablets passed the pharmacopeial requirements for all tablet tests. The formulated tablets showed sustained release characteristics of vitamin $C$ as a tracer, within 8 hrs.

\section{INTRODUCTION}

Immediate release dosage forms result in a quick rise of blood plasma levels with a subsequent decrease due to elimination. The use of sustained release medication could be beneficial in order to maintain therapeutic plasma levels. Furthermore, it would improve the patient compliance with the use of once daily drug administration ${ }^{1}$. Although initial development costs may be high, controlled release dosage forms have the potential to enhance clinical efficacy and reduce the total treatment cost as compared to immediate release dosage forms ${ }^{2}$.

Since the beginning of the epidemic of AIDS, researchers provided the obviousness, at what stage, AIDS could be prevented, treated and be controlled by guaranteeing an optimal nutritional state to the patients ${ }^{3}$. Actually, one can mention that optimal nutrition can help boost immune function, maximize the effectiveness of antiretroviral therapy, reduce the risk of opportinistic infections and chronic 
illnesses such as diabetes and cardiovascular diseases, and contribute to a better overall quality of life ${ }^{4}$. Malnutrition, weight loss, and body cell mass (BCM) depletion have long been observed in individuals with HIV infection and acquired immunodeficiency syndrome and are associated with increased morbidity and mortality ${ }^{5}$ Nutritional deficiency play a significant role in the immunodeficient state. It was also reported that the severity of clinical manifestations of AIDS is proportional to the degree of nutritional deficiency ${ }^{6 \& 7}$.

Since the beginning of the epidemic of AIDS, the free radicals and specifically the antioxidant agents were implied in the pathogenesis of this new syndrome ${ }^{8-10}$. The role of the oxygen free radicals in the HIV/AIDS was the subject of many congresses ${ }^{11 \& 12}$. The nutritional therapy proposed in AIDS, was discussed $^{13 \& 14}$, used at the beginning of the epidemic and still used currently. Studies consistently show that serum antioxidant vitamins and minerals decrease while oxidative stress increases during AIDS progression. The optimization of nutritional status, intervention with foods and supplements, including nutrients and other bio-active food components, are needed to maintain the immune system. Various food components may be recommended to reduce the incidence and severity of infectious illnesses by forms of bioprotection which include reduced oxidative stress due to reactive oxygen species which stimulate HIV replication and AIDS $\operatorname{progression}^{15}$.

Antioxidants are available in the market as capsules. Their release rate is very fast. This leads to depletion of antioxidants from the body within short time. To raise the efficiency of antioxidant system in patients, it is recommended to prolong the residence time of antioxidants. Therefore, the aim of this work is to study the effect of formulation factors on the stability of vitamin $\mathrm{C}$ as a tracer for formulae selected. The second step is to formulate and evaluate sustained release tablets containing antioxidants. This specific sustained release formula has never been tested in AIDS before $^{16}$. The research will be extended to be applied on human HIV positive volunteers after approval of research ethic's committee.

\section{MATERIALS AND METHODS}

\section{Materials}

All materials are of pharmaceutical grades were bought from DistriB3 Company (Marseille).

- Betacarotene 10 CWS (10\%) (Vitamin A),

- Ascorbic acid coated with ethylcellulose (97.5\%) (Vitamin C),

- Tocopherol acetate 50 CWS (50\%) (Vitamin E),

- Selenium yeast $(0.2 \%)$,

- Zinc pidolate (20\%).

Other materials are listed in Table I.

\section{Methods \\ Tracer selection}

Different active principles are present in the formula under investigation: vitamin $\mathrm{A}$, vitamin $\mathrm{C}$, vitamin $\mathrm{E}$, in addition to selenium and zinc. All these materials are of diverse physiochemical nature. For this reason vitamin $\mathrm{C}$ was chosen as a tracer for detection and evaluation of other active principles. Vitamin C was coated with ethylcellulose in order to increase its stability. The dose of vitamin $\mathrm{C}$ in each tablet was $110 \mathrm{mg}$. The wavelength of vitamin $\mathrm{C}$ in $\mathrm{UV}$ was determined in different $\mathrm{pH}$ values $1.2,4.5$ and 6.8 . The stability of vitamin $\mathrm{C}$ at different $\mathrm{pH}$ values was studied.

\section{Pharmaceutical formulation Small scale formulation}

Table II illustrates 16 formula suggested for tablet formulations. All tablets were evaluated according to the requirement of European Pharmacopoeia $2008^{17}$.

Direct compression technique (Frogerais alternative single punch type OA) was used for tablet preparation. Table III illustrates the constituents of tablets according to daily requirement.

Vitamins $\mathrm{A}$ and $\mathrm{E}$ are oily in nature, so it is recommended to use adsorption technique, for preparation of tables. Vitamin $\mathrm{A}$ and $\mathrm{E}$ were adsorbed on Aerosil@ 200 and Lactose respectively to facilitate mixing with other materials. The final formula contains 50/50 active component / excipients.

\section{Large scale formulations}

Trials were made to apply the recommended formula (Table III) in a large 
Table I: List of excipients used in tablet preparations.

\begin{tabular}{|c|c|c|}
\hline Class & Trade name & Chemical name \\
\hline \multirow{3}{*}{ Binders } & Kollidon ${ }^{\circledR}$ K 30 & Homopolymere 1-Ethenyl-2-pyrrolidinone \\
\hline & Kollidon ${ }^{\circledR}$ VA 64 & Polyvinylpyrrolidone \\
\hline & CMC sodium & Sodium carboxymethylcellulose \\
\hline \multirow{3}{*}{ Fillers } & Lactose SD monohydrate & $\begin{array}{l}\text { O-D-Galactopyranosyl-(1(4)- } \alpha \text {-glucopyranose } \\
\text { (anhydrous or monohydrate) }\end{array}$ \\
\hline & Avicel® PH 102 & Microcrystalline cellulose \\
\hline & Dibasic calcium phosphate & Dibasic calcium phosphate dehydrate \\
\hline \multirow{4}{*}{ Lubricants } & Aerosil@ 200 & Sodium dioxide \\
\hline & Magnesium Stearate & Magnesium stearate \\
\hline & Talc & Magnesium silicate \\
\hline & Sodium stearyl fumarate & Sodium stearyl fumarate \\
\hline \multirow{5}{*}{$\begin{array}{l}\text { Sustained } \\
\text { release } \\
\text { excipients }\end{array}$} & Precirol® ATO 5 & Glycerol stearyl palmitate \\
\hline & Compritol® 888 ATO & Glycerol tribehnate \\
\hline & Eudragit ${ }^{\circledR}$ RS PO & Ethylacrylate (copolymer) \\
\hline & $\begin{array}{l}\text { Metolose } 90 \text { SH } 400 / \\
1500 / 100000\end{array}$ & Methylcellulose \\
\hline & EC powder & Ethylcellulose \\
\hline
\end{tabular}

Table II: Tablets ingredients.

\begin{tabular}{|c|c|c|c|c|}
\hline Mix & Binders & Fillers & Lubricants & $\begin{array}{c}\text { Sustained release } \\
\text { excipients }\end{array}$ \\
\hline 1 & Kollidon K30 & Lactose SD monohydrate & Aerosil 200 & Precirol ATO5 \\
\hline 2 & Kollidon K30 & Avicel PH 102 & $\begin{array}{l}\text { Sodium Stearyl } \\
\text { fumarate }\end{array}$ & Metolose 90 SH400 \\
\hline 3 & Kollidon VA64 & Lactose SD monohydrate & Talc & Compritol 888 ATO \\
\hline 4 & Kollidon VA64 & $\begin{array}{c}\text { Dibasic calcium } \\
\text { phosphate }\end{array}$ & $\begin{array}{l}\text { Sodium Stearyl } \\
\text { fumarate }\end{array}$ & Precirol ATO5 \\
\hline 5 & Kollidon VA64 & Lactose SD monohydrate & Aerosil 200 & $\begin{array}{c}\text { Metolose } 90 \\
\text { SH100000 }\end{array}$ \\
\hline 6 & Kollidon VA64 & $\begin{array}{c}\text { Dibasic calcium } \\
\text { phosphate }\end{array}$ & $\begin{array}{l}\text { Magnesium } \\
\text { Stearate }\end{array}$ & Metolose 90 SH1500 \\
\hline 7 & Kollidon VA64 & Avicel PH 102 & Talc & Eudragit RS PO \\
\hline 8 & CMC sodium & Avicel PH 102 & Talc & Precirol ATO5 \\
\hline 9 & CMC sodium & Lactose SD monohydrate & $\begin{array}{l}\text { Magnesium } \\
\text { Stearate }\end{array}$ & $\begin{array}{l}\text { Metolose } 90 \\
\text { SH100000 }\end{array}$ \\
\hline 10 & CMC sodium & Avicel PH 102 & Aerosil 200 & Metolose 90 SH1500 \\
\hline 11 & CMC sodium & Lactose SD monohydrate & Talc & Ethylcellulose \\
\hline 12 & CMC sodium & $\begin{array}{c}\text { Dibasic calcium } \\
\text { phosphate }\end{array}$ & $\begin{array}{l}\text { Sodium Stearyl } \\
\text { fumarate }\end{array}$ & Eudragit RS PO \\
\hline 13 & Kollidon K30 & $\begin{array}{c}\text { Dibasic calcium } \\
\text { phosphate }\end{array}$ & Aerosil 200 & Compritol 888 ATO \\
\hline 14 & Kollidon K30 & $\begin{array}{c}\text { Dibasic calcium } \\
\text { phosphate }\end{array}$ & Talc & Metolose 90 SH400 \\
\hline 15 & Kollidon K30 & Lactose SD monohydrate & $\begin{array}{c}\text { Sodium Stearyl } \\
\text { fumarate }\end{array}$ & Metolose 90 SH1500 \\
\hline 16 & Kollidon K30 & Avicel PH 102 & $\begin{array}{l}\text { Magnesium } \\
\text { Stearate }\end{array}$ & Ethylcellulose \\
\hline
\end{tabular}


Table III: Tablet formulation according to daily requirement.

\begin{tabular}{|l|c|c|}
\hline \multicolumn{1}{|c|}{ Materials } & $\begin{array}{c}\text { Weight in } \\
\text { each tablet } \\
(\mathrm{mg})\end{array}$ & $\begin{array}{c}\text { Weight for 100 } \\
\text { tablets (g) }\end{array}$ \\
\hline 1- Active components & 50.000 & 5.000 \\
Vitamin A & 112.820 & 11.282 \\
Vitamin C & 24.000 & 2.400 \\
Vitamin E & 60.000 & 6.000 \\
Zinc & 50.000 & 5.000 \\
Selenium & & \\
2- Excipients & 29.68 & 2.96 \\
- Kollidon K30 & 178.09 & 17.81 \\
- Dibasic calcium phosphate & 29.07 & 2.97 \\
- Talc & 59.36 & 5.94 \\
- Metolose 90 SH400 & \multicolumn{2}{|}{} \\
\hline
\end{tabular}

scale, using $1.187 \mathrm{~kg}$ to produce 2000 tablets. Frogerais PR16 Rotary tablet press was used (punch of $11 \mathrm{~mm}$ ). Talc was selected as a lubricant for its cheap price, and being not sticky to the machine.

\section{Tablets evaluation}

Hardness test, stability of vitamin $\mathrm{C}$ in tablets, disintegration test, content uniformity and friability tests were performed for all tablets defined in the experimental part.

\section{Hardness test}

Tablets were evaluated using hardness tester (TBH 200D, Erweka GmbH, Germany).

\section{Stability of vitamin $\mathbf{C}$ in granules}

Uncoated and coated vitamin $\mathrm{C}$ granules, were pulverized separately in a mortar and dissolved in one liter aqueous media $\mathrm{pH}$ 1.2. The contents were measured during $8 \mathrm{hrs}$ at room temperature and at $37^{\circ} \mathrm{C}$, using UV spectrophotometer (Shimadzu-150-02 Seisakusho Ltd., Tokyo, Japan), at wavelength $243.4 \mathrm{~nm}$. The variations between tablets were calculated.

\section{Disintegration test}

Disintegration test was performed according to European Pharmacopoeia ${ }^{17}$. The test was performed on six tablets (Erweka tablet disintegration apparatus $\mathrm{GmbH}$, Germany).

\section{Content uniformity}

One tablet was powdered in a mortar, and dissolved in one liter $0.1 \mathrm{~N} \mathrm{HCl}(\mathrm{pH} 1.2)$. The test was repeated ten times. The contents of each tablet of vitamin $C$ were determined using UV spectrophotometer at wavelength $\lambda=243.4$ $\mathrm{nm}$.

\section{Friability test}

The friability test was performed using Erweka tester (Germany). The apparatus was adjusted at 25 rounds/minute during 4 minutes ${ }^{17}$. The test was performed on 10 tablets, and repeated three times, and the average was calculated.

\section{Dissolution test}

The dissolution test ${ }^{17}$ was performed on two optima formulae selected by previous tests ${ }^{18}$. The test was performed using dissolution apparatus (SOTAX DT3 German). Six tablets for each optimum lot were used for dissolution test, using paddle method $(50 \mathrm{rpm})$. Dissolution media was one liter $0.1 \mathrm{~N} \mathrm{HCl}(\mathrm{pH}$ 1.2 ), at $37^{\circ} \mathrm{C}$ during $8 \mathrm{hrs}$.

\section{RESULTS AND DISCUSSION}

\section{Small scale formulations \\ Tracer evaluation}

Vitamin $\mathrm{C}$ was used as a tracer for tablets evaluation. The results indicated that no interference was seen between ingredients 
present in the formula with vitamin $\mathrm{C}$ evaluation at $\mathrm{pH}$ 1.2.

Maximum absorbance of vitamin $\mathrm{C}$ was found to be $243.4 \mathrm{~nm}, 256 \mathrm{~nm}$ and $265.4 \mathrm{~nm}$ in $\mathrm{pH} 1.2, \mathrm{pH} 4.5$ and $\mathrm{pH} 6.8$ respectively. A linear correlation between absorbance and concentration of vitamin $\mathrm{C}(\mathrm{pH} 1.2)$ was found (up to $132 \mathrm{mg} / \mathrm{L}$ ).

\section{Stability of vitamin C}

The stability of uncoated vitamin $\mathrm{C}$ tablets in different $\mathrm{pH} 1.2,4.5$ and 6.8 at room temperature was studied. The results revealed that vitamin $\mathrm{C}$ is most stable at $\mathrm{pH} 1.2$ compared with the media of $\mathrm{pH} 4.5$ and $\mathrm{pH} 6.8$.
Therefore, the media of $\mathrm{pH} 1.2$ was selected for testing the sustained release behavior for tablets.

On the other hand, the stability of vitamin C granules coated with ethylcellulose was studied. The granules were dissolved in $\mathrm{HCl}$ ( $\mathrm{pH}$ 1.2). The stability was performed at room temperature and at $37^{\circ} \mathrm{C}$. It is obvious that the loss of vitamin $\mathrm{C}$ during $8 \mathrm{hrs}$ attained $1.35 \%$ at ambient temperature and $3.55 \%$ at $37^{\circ} \mathrm{C}$ for uncoated sample (Fig. 1).

The percent loss of vitamin $\mathrm{C}$ coated with ethylcellulose at $\mathrm{pH} 1.2$ during $8 \mathrm{hrs}$ attained $0.68 \%$ at ambient temperature and $2.50 \%$ at $37^{\circ} \mathrm{C}$ (Fig. 2).

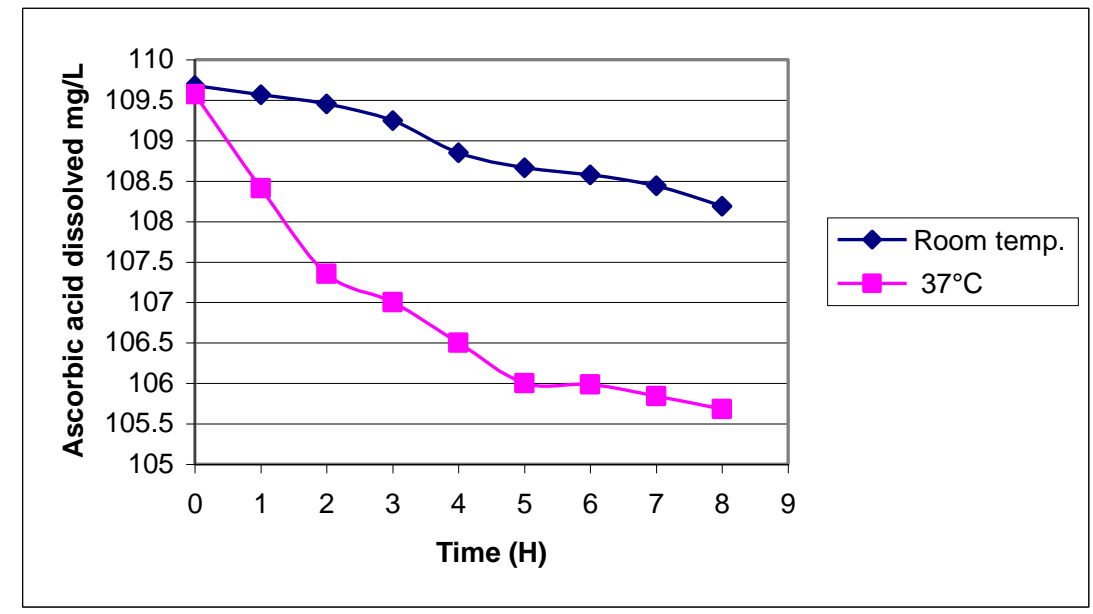

Fig. 1: Stability of uncoated ascorbic acid granules in media of $\mathrm{pH}(1.2)$ at different temperatures.

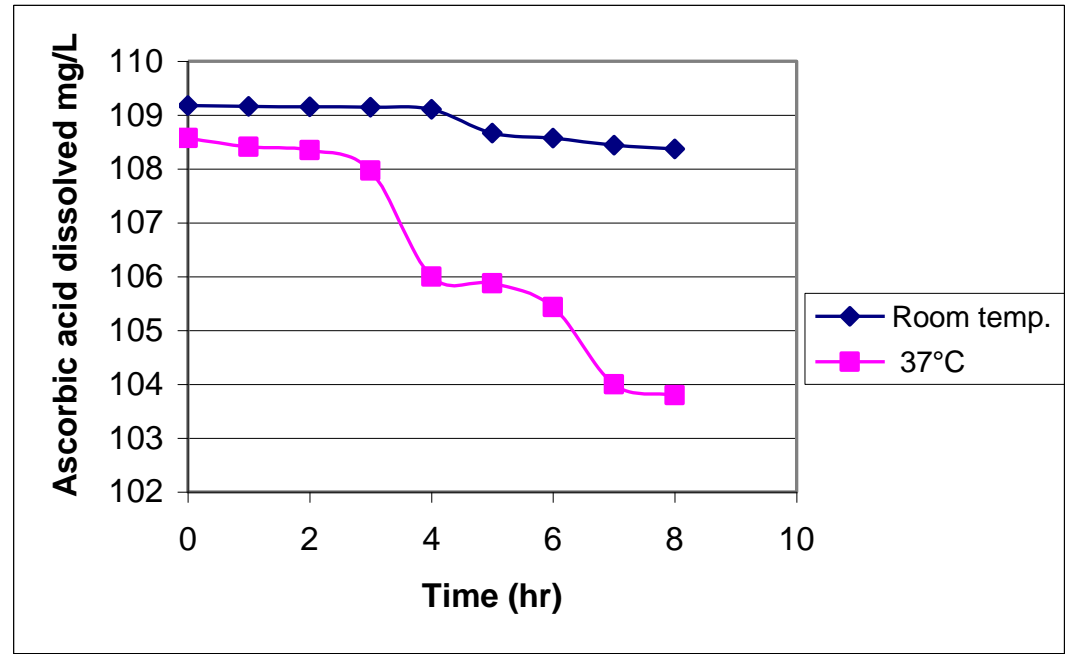

Fig. 2: Stability of coated granules with ethylcellulose using a media of $\mathrm{pH}$ (1.2) at different temperatures. 


\section{Tablets formulation}

Table IV illustrates different parameters for different combinations of tablet excipients namely; apparent volume (V10-V500), flowability, weight variations, hardness, disintegration time and amount dissolved after $8 \mathrm{hrs}$ from tablets. All data recorded obey the pharmacopeial requirements ${ }^{17}$.

Formula 2 and 14 were selected according to the best friability and hardness requirements (Table IV). The dissolution behavior of vitamin $\mathrm{C}$ from tablets depends mainly on the behavior of excipients in dissolution medium. Consequently, the hydrophilic excipients, e.g. lactose is responsible for rapid liberation of drug. On the other hand, on using Aerosil (F10) (Table II), the dissolution rate decreased.

The same results were obtained on using Compritol, Precirol and dibasic calcium phosphate as filler (F3, F4, and F14), and also on using CMC sodium with Avicel (F8). Moreover, CMC sodium mixed with Avicel, improved the compressibility of tablets. This hypothesis, could be applied on F10, F13 and F14 which contain Metelose/CMC, Kollidon/ Compritol and Kollidon/methylcellulose respectively.

It is worthy to note that when two viscous materials with soluble or insoluble fillers, may increase or decrease the dissolution behavior of the active principles respectively.

According to aforementioned discussion; the two formula of choice are F2 and F14 which gave the recommended behavior (Table IV and Fig. 3). The two formula selected differ only on filler and lubricant used. Talc was chosen (F14) because it is the cheapest.

\section{Tablets evaluation \\ Flowability test}

The flowability of the tablet formulae in powder form $(100 \mathrm{~g})$ was 5.8 seconds for formula F2 and 5 seconds for formula F14, suggesting better weight uniformity for formula F14 ${ }^{17}$.

\section{Apparent volume of powder}

Using $100 \mathrm{~g}$ powder, the initial volume was measured $\left(\mathrm{V}_{\mathrm{o}}\right)$. After using 10 and 490 vibrations, $\mathrm{V}_{10}$ and $\mathrm{V}_{500}$ were recorded respectively. The results are shown in Table V. This value is within the limits of recommended value $^{17}$.

\section{Uniformity of weight and hardness}

Theoretical weight was $0.593 \mathrm{~g}$. The mean weight (Table IV) for 10 tablets of Formula F2 was $0.594 \mathrm{~g}$; the variation percent was $1.85 \%$. The mean weight for 10 tablets of Formula F14 was $0.595 \mathrm{~g}$; the variation percent was $1.06 \%$. This is within pharmacopeial limits ${ }^{17}$. Concerning hardness test $(\mathrm{kg} / \mathrm{ton})$, the mean for 10 tablets equals 4.57 for formula F2 and 4.65 for formula F14.

\section{Uniformity of content}

The results obtained were within the pharmacopeial limits ${ }^{17}$. The mean content uniformity is $110 \mathrm{mg} \pm 3 \%$ for formula F2 and $110 \mathrm{mg} \pm 2.5 \%$ for formula F14.

\section{Friability test}

The mean weight of 20 tablets of formula F2 before test, was $\mathrm{P}_{\mathrm{o}}=11.830 \mathrm{~g}$, and the mean weight after test was $\mathrm{P}=11.724 \mathrm{~g}$. The mean weight of 20 tablets of formula F14 before test, was $P_{o}=11.768 \mathrm{~g}$, and the mean weight after test was $\mathrm{P}=11.694 \mathrm{~g}$. This confirms the requirement for tablets: loss was less than $1 \%$ for both formulae (Table IV).

\section{Dissolution test}

Six tablets from two patches (F2 \& F14) were used for dissolution test. One of which contained sodium stearyl fumarate (Fig. 4) and the other contained talc as a lubricant (Fig. 5). Figures (4 and 5) show the dissolution rate of six tablets. The results revealed that a sustained release requirement was attained along $8 \mathrm{hrs}$. The drug delivery system exhibits sustained release and succeeded in delivering a total cumulative ascorbic acid quantity of $76.3 \%$ (SD 21.27) of the initial theoretical amount after $8 \mathrm{hrs}$ for formula F2 (Fig. 4) and 79.9\% for formula F14 (SD 22.2) (Fig. 5).

\section{Large scale tablet formulations}

Talc was selected as a lubricant, for its cheap price, and being not sticky to the machine. So, Formula F14 mentioned in Table VI was used to prepare 2000 tablets. All quality control tests were applied to the mixed ingredients in powder form. The results of apparent volume were found to be:

Initial volume $\mathrm{V}_{\mathrm{o}}=242 \mathrm{ml}$

$$
\begin{aligned}
& \mathrm{V}_{10}=237 \mathrm{ml} \\
& \mathrm{V}_{500}=219 \mathrm{ml} \\
& \mathrm{V}_{10}-\mathrm{V}_{500}=18 \mathrm{ml} .
\end{aligned}
$$


Table IV: Pharmaceutical evaluation of excipients and tablets using different formulation.

\begin{tabular}{|c|c|c|c|c|c|c|c|}
\hline $\begin{array}{c}\text { Formula } \\
\text { No. }\end{array}$ & $\begin{array}{c}\text { V10- } \\
\text { V500 } \\
(\mathrm{ml})\end{array}$ & $\begin{array}{c}\text { Flowability } \\
(100 \mathrm{~g} / \mathrm{sec} .)\end{array}$ & $\begin{array}{c}\text { Mean } \\
\text { weight } \pm \mathrm{SD}\end{array}$ & $\begin{array}{c}\text { Hardness } \\
(\mathrm{kg} / \mathrm{ton})\end{array}$ & Friability & $\begin{array}{c}\text { Disintegration } \\
\text { time } \\
(\text { Min })\end{array}$ & $\begin{array}{c}\text { Dissolution } \\
\text { after 8 hrs } \\
(\mathrm{mg} / \mathrm{L})\end{array}$ \\
\hline 1 & 21 & 8 & $564 \pm 2.4$ & 2.12 & 1.2 & 25 & $105.9 \%$ \\
\hline 2 & 18 & 5.8 & $594 \pm 1.85$ & 4.57 & $<1$ & $>30$ & $76.3 \%$ \\
\hline 3 & 22 & 10 & $592 \pm 2.6$ & 3.1 & $>1$ & $>30$ & $92.6 \%$ \\
\hline 4 & 23 & 8 & $580 \pm 2.7$ & 4 & $<1$ & $>30$ & $84.3 \%$ \\
\hline 5 & 22 & 11 & $585 \pm 2.9$ & 3.2 & $<1$ & 23 & $102.8 \%$ \\
\hline 6 & 22 & 11 & $582 \pm 2.7$ & 3.6 & $<1$ & 30 & $90.9 \%$ \\
\hline 7 & 20 & 8 & $568 \pm 2.4$ & 3.9 & $<1$ & 30 & $85.5 \%$ \\
\hline 8 & 19 & 9 & $582 \pm 2.2$ & 3.6 & $<1$ & 30 & $89.3 \%$ \\
\hline 9 & 20 & 12 & $578 \pm 2.0$ & 4 & $<1$ & 28 & $92.1 \%$ \\
\hline 10 & 22 & 11 & $582 \pm 2.1$ & 3.6 & 1.1 & 24 & $99.5 \%$ \\
\hline 11 & 21 & 10 & $582 \pm 2.1$ & 3.2 & 1 & $>30$ & $87.3 \%$ \\
\hline 12 & 22 & 12 & $586 \pm 2.2$ & 3.6 & 1.1 & $>30$ & $85.7 \%$ \\
\hline 13 & 23 & 13 & $560 \pm 2.4$ & 4.3 & $<1$ & $>30$ & $92.6 \%$ \\
\hline 14 & 18 & 5 & $595 \pm 1.06$ & 4.65 & $<1$ & $>30$ & $79.9 \%$ \\
\hline 15 & 21 & 8 & $572 \pm 2.4$ & 3.8 & 1.1 & $>30$ & $87.7 \%$ \\
\hline 16 & 21 & 11 & $585 \pm 2.2$ & 3.9 & 1 & $>30$ & $89.1 \%$ \\
\hline
\end{tabular}

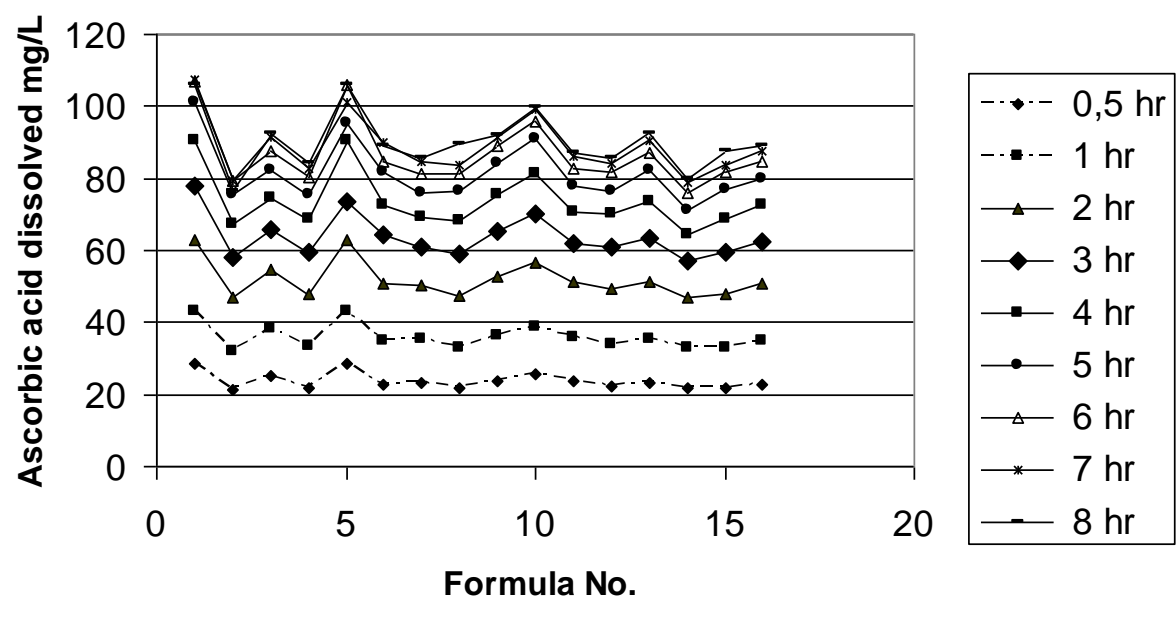

Fig. 3: Ascorbic acid dissolved from each formula selected. 
Table V: Apparent volume of powder for both formulae.

\begin{tabular}{|c|c|c|}
\hline & Formula F2 & Formula F14 \\
\hline $\mathrm{V}_{\mathrm{o}}$ & $245 \mathrm{~mL}$ & $240 \mathrm{~mL}$ \\
\hline $\mathrm{V}_{10}$ & $241 \mathrm{~mL}$ & $235 \mathrm{~mL}$ \\
\hline $\mathrm{V}_{500}$ & $223 \mathrm{~mL}$ & $218 \mathrm{~mL}$ \\
\hline $\mathrm{V}_{10}-\mathrm{V}_{500}$ & $18 \mathrm{~mL}$ & $17 \mathrm{~mL}$ \\
\hline
\end{tabular}

Table VI: Ingredients for the two formula selected.

\begin{tabular}{|c|c|c|}
\hline & Formula F2 & Formula F14 \\
\hline Antioxidants & $\begin{array}{c}\text { Vitamin A, C, E, zinc, } \\
\text { selenium }\end{array}$ & $\begin{array}{c}\text { Vitamin A, C, E, zinc, } \\
\text { selenium }\end{array}$ \\
\hline Binders & KOLLIDON K30 & KOLLIDON K30 \\
\hline Fillers & Avicel PH 102 & Dibasic calcium phosphate \\
\hline Lubricants & Sodium Stearyl fumarate & Talc \\
\hline Sustained release excipients & Metolose 90 SH400 & Metolose 90 SH400 \\
\hline
\end{tabular}

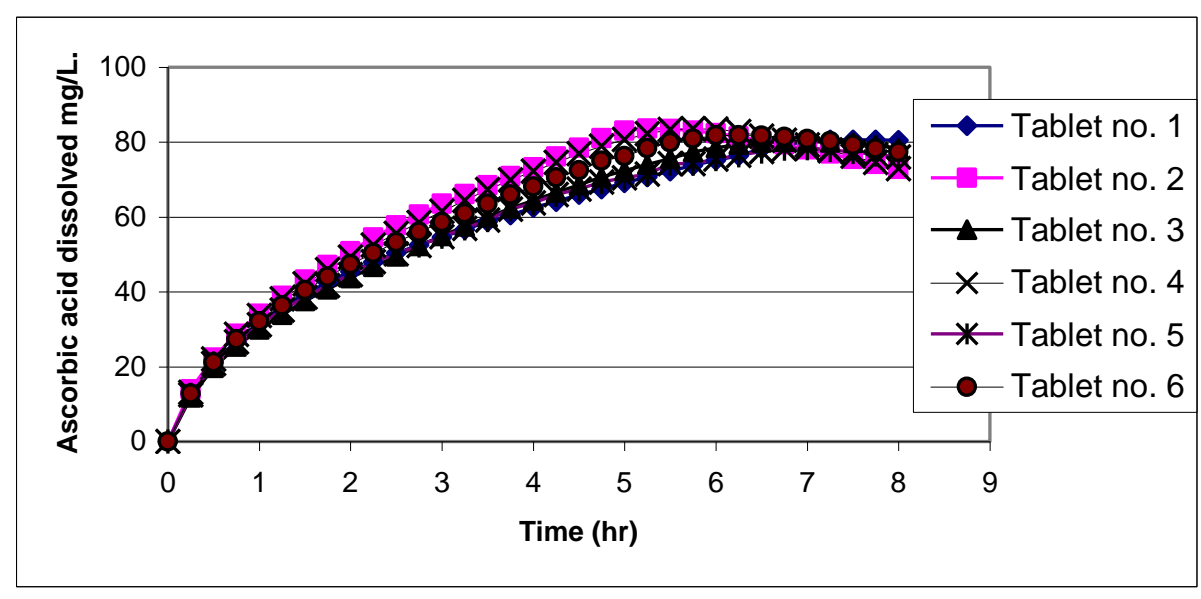

Fig. 4: Dissolution profile of 6 tablets using sodium stearyl fumarate as a lubricant and dissolution media of $\mathrm{pH} 1.2$ at $37^{\circ} \mathrm{C}$.

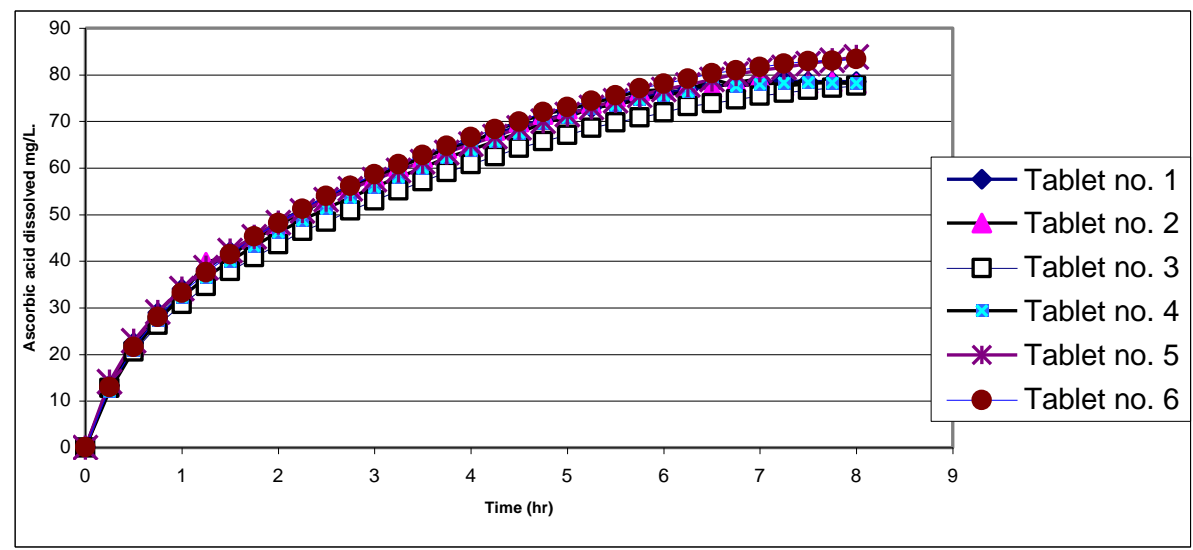

Fig. 5: Dissolution profile of 6 tablets using talc as a lubricant and dissolution media of pH 1.2 at $37^{\circ} \mathrm{C}$. 
A sample was taken from tablets and subjected to the following tests.

\section{Uniformity of weight and hardness}

The mean weight of 10 tablets was 0.609 $\mathrm{g}$, the $\%$ variation $4.4 \%$. This confirms the pharmacopoeial limits ${ }^{17}$. The mean hardness was $4.04 \pm 0.6 \mathrm{~kg} / \mathrm{ton}$.

\section{Friability test}

About $5 \mathrm{mg}$ loss represents less than $0.8 \%$.

\section{Disintegration time}

Disintegration time was found to be more than 30 min.

All the aforementioned results fulfill the requirements for sustained release tablet formulations ${ }^{17}$.

\section{Dissolution rate}

Figure 6 illustrates the dissolution profile of six tablets, from scale up patch. The results revealed that a sustained release requirement of vitamin $\mathrm{C}$ was attained along $8 \mathrm{hrs}$. Moreover, the percent cumulative as ascorbic acid was found to be $86.7 \%$ (SD 23.2) after $8 \mathrm{hrs}$.

\section{Conclusion}

In the present study, it is possible to verify the aim from this research. Formulation of a sustained release dosage form was performed to prolong the residence time of antioxidants (8 hrs) using vitamin $\mathrm{C}$ as a tracer. The research will be extended to evaluate the recommended formulae in human volunteers after approval of research ethic's committee.

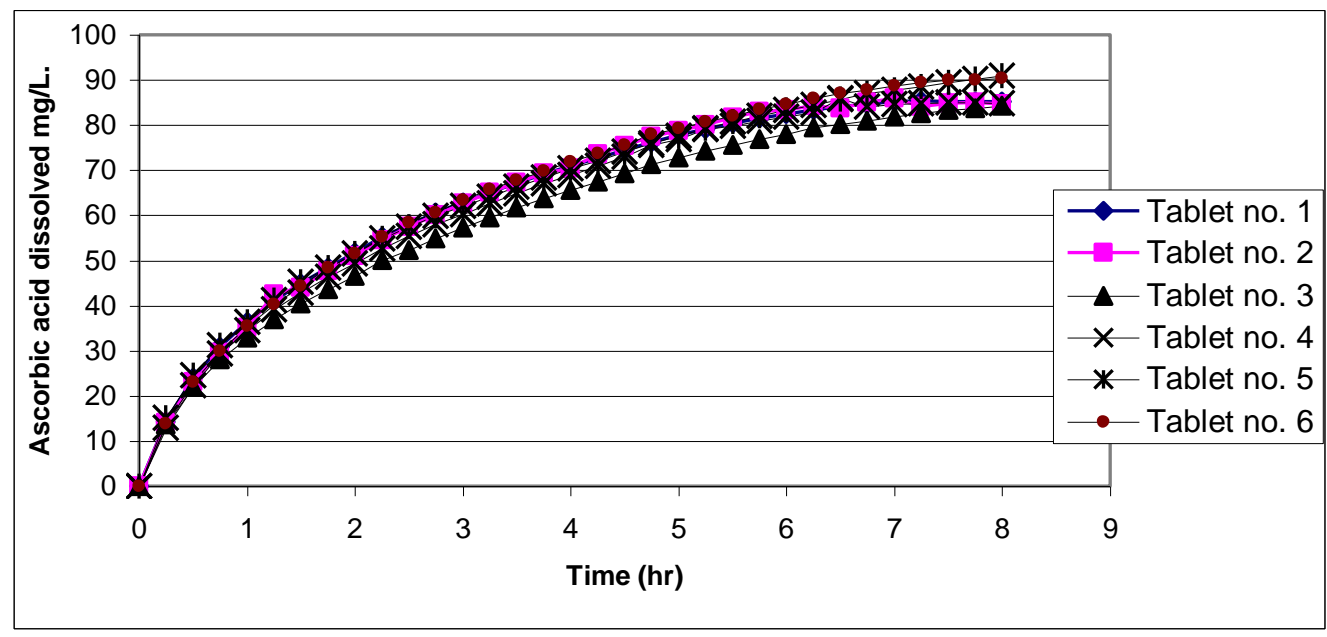

Fig. 6: Dissolution profile of 6 tablets as a sample from large scale formulation using talc as a lubricant and dissolution media of $\mathrm{pH} 1.2$ at $37^{\circ} \mathrm{C}$. 


\section{REFERENCES}

1. J. Collet and C. Moreton, "ModifiedRelease Per Oral Dosage Forms. Pharmaceutics, the Science of Dosage Form Design", M. E. Aulton Ed., Harcourt Publishers Limited, London, 2002, pp. 289-305.

2. R. S. Saks and L. B. Gardner, "The pharmacoeconomic value of controlledrelease dosage forms", J. Control Release, 48, 237-242 (1997).

3. V. K. Jain and R. D. Chandra, "Does nutritional deficiency predispose to acquired immunodeficiency syndrome?", Nutr. Res., 4, 537 (1984).

4. L. Highleyman, "Nutrition and HIV", Beta, 18 (2), 18-32 (2006).

5. C. P. Earthman, "Evaluation of nutrition assessment parameters in the presence of human immunodeficiency virus infection", Nutr. Clin. Pract., 19 (4), 330-339 (2004).

6. R. T. Chlebowski, "Significance of altered nutritional status in acquired immune deficiency syndrome (AIDS)", Nutr. Cancer, 7, 85-91 (1985).

7. L. Chelluri and M. S. Jastremski, "Incidence of malnutrition in patients with acquired immunodeficiency syndrome", Nutr. Clin. Pract., 4, 16-18 (1989).

8. E. Papadopulos-Eleopulos, "Reappraisal of AIDS - Is the oxidation induced by the risk factor the primary cause?", Medical Hypothesis, 25, 151-162 (1988).

9. G. O. Coodley, "Nutritional deficiency and AIDS", Ann. Intern. Med., 113 (10), 807-809 (1990).

10. B. M. Dworkin, "Selenium deficiency in HIV infection and acquired immunodeficiency syndrome (AIDS)", Chem. Biol. Interact., 91 (2-3), 181-6 (1994).
11. Piette, et al., "Molecular mechanisms of virus activation by free radicals", Collection of 5 articles presented at a conference on "The Place of Oxygen Free Radicals in HIV Infection", Les Deux Alpes, France, January 1993. ChemicoBiological Interactions, 91, 79-132 (1993).

12. A. Favier, "The place of oxygen free radicals in HIV infection", ibid., 91, 77224 (1994).

13. G. T. Keusch and D. M. Thea, "Malnutrition in AIDS", Med. Clin. NA, 77 (4), 795-814 (1993).

14. L. K. Mahan and S. Escott-Stump, "Medical Nutritional Therapy for Human Immunodeficiency Virus (HIV) Infection and Acquired Immunodeficiency Syndrome (AIDS)", In: Food, Nutrition, and Diet Therapy, Philadelphia: W.B. Saunders Company, 2000, pp. 889-911.

15. M. Suttajit, "Advances in nutrition support for quality of life in HIV+/AIDS", Asia Pac. J. Clin. Nutr., 16 Suppl. 1, 318-322 (2007).

16. J. Joachim, J. Kister, Y. Bertacchini and H. Dou, "Intelligence économique et système d'information (analyse à partir d'un sujet stratégique: HIV et formulation dynamique en supplémentation nutritionnelle)", Informations Sciences for Decision Making, 24, 1-39 (2006).

17. European Pharmacopoeia, $6^{\text {th }}$ ed. Strasbourg, France (2008).

18. Bentejac and Coll., "Les essais de dissolution des formes solides pour voie orale. Mise au point biopharmaceutique et relations avec la biodisponibilité", S.T.P. Pharma Pratiques, 2 (6), 500-506 (1992). 